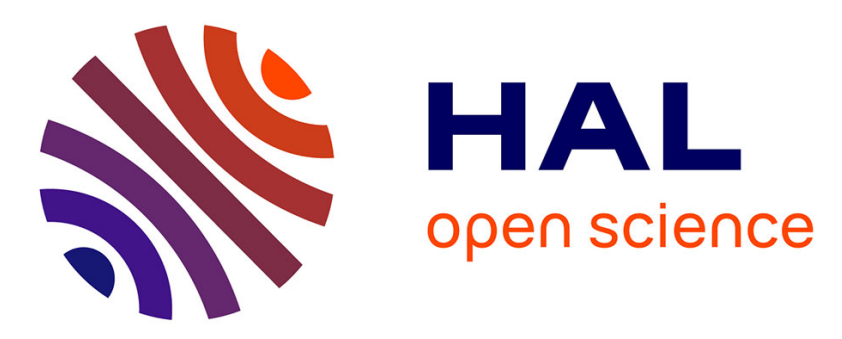

\title{
Evaluation of the mineralizing potential of the Mbengwi plutonics, Northwestern Cameroon, Central Africa
}

Benoît Joseph Mbassa, Emmanuel Njonfang, Michel Grégoire, Zénon Itiga, Pierre Kamgang, Mathieu Benoit, Paul Désiré Ndjigui, Caroline Neh Ngwa, Junior Désiré Nolla

\section{To cite this version:}

Benoît Joseph Mbassa, Emmanuel Njonfang, Michel Grégoire, Zénon Itiga, Pierre Kamgang, et al.. Evaluation of the mineralizing potential of the Mbengwi plutonics, Northwestern Cameroon, Central Africa. Arabian Journal of Geosciences, 2018, 11 (21), 10.1007/s12517-018-4018-0 . hal-02327623

\section{HAL Id: hal-02327623 https://hal.science/hal-02327623}

Submitted on 12 Nov 2020

HAL is a multi-disciplinary open access archive for the deposit and dissemination of scientific research documents, whether they are published or not. The documents may come from teaching and research institutions in France or abroad, or from public or private research centers.
L'archive ouverte pluridisciplinaire HAL, est destinée au dépôt et à la diffusion de documents scientifiques de niveau recherche, publiés ou non, émanant des établissements d'enseignement et de recherche français ou étrangers, des laboratoires publics ou privés. 
See discussions, stats, and author profiles for this publication at: https://www.researchgate.net/publication/328624983

\section{Evaluation of the mineralizing potential of the Mbengwi plutonics, Northwestern Cameroon, Central Africa}

Article in Arabian Journal of Geosciences · November 2018

DOI: 10.1007/s12517-018-4018-0

\section{CITATIONS}

9 authors, including:

Benoît Joseph Mbassa

Institute for Geological and Mining Research

18 PUBLICATIONS 23 CITATIONS

SEE PROFILE

Michel Grégoire

CNRS-INSU

232 PUBLICATIONS 3,670 CITATIONS

SEE PROFILE
225

Njonfang Emmanuel

104 PUBLICATIONS 1,384 CITATIONS

SEE PROFILE

Zénon Itiga

Institute for Geological and Mining Research (IRGM), Cameroon, Yaoundé 15 PUBLICATIONS 38 CITATIONS

SEE PROFILE

Some of the authors of this publication are also working on these related projects:

Continental lithosphere View project

Origin and evolution of ultra-refractory peridotites in oceanic large igneous provinces View project 


\title{
Evaluation of the mineralizing potential of the Mbengwi plutonics, Northwestern Cameroon, Central Africa
}

\author{
Benoît Joseph Mbassa ${ }^{1}$ - Emmanuel Njonfang ${ }^{2} \cdot$ Michel Grégoire $^{3} \cdot$ Zénon Itiga $^{1}$ • Pierre Kamgang ${ }^{4}$. \\ Mathieu Benoit ${ }^{3}$. Paul Désiré Ndjigui ${ }^{4}$. Caroline Neh Ngwa ${ }^{1}$ • Junior Désiré Nolla ${ }^{5}$
}

Received: 14 November 2017 / Accepted: 18 October 2018

(C) Saudi Society for Geosciences 2018

\begin{abstract}
The Mbengwi area consists of Cenozoic alkaline rocks and Pan-African calc-alkaline plutonics. The alkaline magmatic series include volcanics (basanites, hawaiites, mugearite, and rhyolite) and syenites while the calc-alkaline plutonics comprise various granitoids (granites, granodiorites, quartz monzonites, and monzonites) associated with monzodiorites. These plutonics are calcalkaline, metaluminous to weakly peraluminous, mostly I-type, displaying high potassic to shoshonitic affinities. Their magmas are relatively evolved and typically result from melting of the lower continental crust with variable involvement of the oceanic crust. According to the ranges of their $\mathrm{Rb} / \mathrm{Sr}, \mathrm{Zr} / \mathrm{Hf}$, and $\mathrm{K} / \mathrm{Rb}$ ratios, these magmas have mostly not undergone post-magmatic hydrothermal activity which would lead to mineralization. With regard to their contents in certain elements such as $\mathrm{Sr}, \mathrm{Rb}$, and $\mathrm{Ba}$ in addition to their gradient in $\mathrm{Sm} / \mathrm{Eu}$ and $\mathrm{Rb} / \mathrm{Ba}$ ratios, the Mbengwi plutonics are typical of granitoids devoid of $\mathrm{U}$ and $\mathrm{Ta}$ deposits. They are also barren in $\mathrm{Sn}, \mathrm{W}$, and Mo but mostly productive regarding $\mathrm{Cu}, \mathrm{Zn}$, and $\mathrm{Fe}(\mathrm{Au})$ skarn.
\end{abstract}

Keywords Cameroon $\cdot$ Central Africa $\cdot$ Pan-African $\cdot$ Calc-alkaline plutonics $\cdot$ Mineralizing potential

\section{Introduction}

Determining the mineralizing potential of intrusive bodies is important because every specific type of granite is usually accompanied with a specific type of ore deposit. Numerous precious metal deposits are spatially, temporally, and genetically associated to various types of granitic rocks (Eugster

Benoît Joseph Mbassa

benjo_mbassa@yahoo.fr

1 Institute of Geological and Mining Research (IRGM), Branch for Volcanological and Geophysical Research (ARGV), P.O. Box 370, Buea, Cameroon

2 Laboratory of Geology, Higher Teacher Training College, University of Yaoundé I, P.O. Box 47, Yaoundé, Cameroon

3 Géosciences-Environnement-Toulouse, UMR 5563, Observatoire Midi Pyrénées, Université Paul-Sabatier, 14, avenue Édouard-Belin, 31400 Toulouse, France

4 Department of Earth Sciences, Faculty of Sciences, University of Yaoundé I, P.O. Box 812, Yaoundé, Cameroon

5 Institute of Geological and Mining Research, P.O. Box 4110, Yaoundé, Cameroon
1985; Sillitoe 1996). It had been proved that most Sn, W and several rare metal (Ta, Nb, Li, Be, Zr, Ga, REE) deposits, above $60 \%$ of $\mathrm{Cu}$ resources, approximately $10 \%$ of $\mathrm{Fe}, \mathrm{Au}$, $\mathrm{Zn}, \mathrm{Pb}, \mathrm{Ag}$ and $\mathrm{U}$, in addition to many minor metals $(\mathrm{Bi}, \mathrm{Cd}$, $\mathrm{Sb}, \mathrm{Te}, \mathrm{Re}, \mathrm{In}, \mathrm{Sc}$ ) are related to granitic rocks (Sillitoe 1996). Furthermore, Ghodsi et al. (2016) found that, calc-alkaline Itype magmas have a high ability to bear and concentrate base metals, notably $\mathrm{Fe}, \mathrm{Cu}, \mathrm{Mo}$, and $\mathrm{Au}$, while S-type magmas involve aqueous fluids containing $\mathrm{Sn}, \mathrm{W}$, and base metals.

Although it has been evidenced that Neoproterozoic granitoids from Cameroon host various deposits such as rare metals (Sn-W-REE; Milesi et al. 2006), very few particular attention has been focused on the geology and mineral potential of western Cameroon. Moreover, the studied area has never been so far subject of any mining exploration study. However, Mbassa (2015) revealed unusual remarkable high contents of the Mbengwi plutonics in certain elements such as $\mathrm{Cu}, \mathrm{Sn}, \mathrm{Th}, \mathrm{Pb}$, and $\mathrm{Zn}$, which deserve a particular attention. In this paper, field works, petrographic features, and geochemical analysis are compiled to differentiate the Mbengwi PanAfrican rocks either as productive or barren. We are looking forward to clarify if there may be a relationship between the geochemical composition of the studied plutonics and a possible metal mineralization. Therefore, this paper targets to 
evaluate the mineralizing potential of the Mbengwi plutonic rocks, in comparison with the worldwide renowned productive or sterile magmatic rocks.

\section{Geological setting}

The Central African fold belt (CAFB; Fig. 1) known as a witness of the Pan-African orogeny in Cameroon is represented by granitic rocks and meta-volcano-sedimentary formations. This CAFB is divided into three domains: (i) the southern nappes consisting of Pan-African metamorphic units which was thrust onto the Archean Congo craton towards the south; (ii) the central area or AdamawaYadé domain, bounded by the Sanaga and TcholliréBanyo faults (Fig. 1b), consists of Neoproterozoic metasedimentary series and various syn- to post-kinematic calc-alkaline granitoids; (iii) the northern domain that consists of the Neoproterozoic volcano-sedimentary schists, gneisses, and orthogneisses. Overall, the granitic rocks cover a significant surface both in central and western Cameroon. They derived from different sources such as lithospheric mantle (Tchameni et al. 2006; Djouka-
Fonkwé et al. 2008), lower continental crust (Nzolang et al. 2003; Nzenti et al. 2006; Mbassa et al. 2016), or mixing between those two components (Njanko et al. 2006; Kwékam et al. 2010, 2013).

The studied zone is circumscribed between the parallels $6^{\circ} 06^{\prime}$ and $5^{\circ} 58^{\prime}$ North and the meridians $9^{\circ} 57^{\prime}$ and $10^{\circ} 06^{\prime}$ East, and lithologically marked by the presence of PanAfrican plutonics, Cenozoic magmatic rocks, and sedimentary series (Fig. 1c). The Cenozoic bimodal alkaline magmatic series consist of lavas and syenites belonging to the same magmatic episode (Mbassa et al. 2012). The composition of volcanic rocks ranges from basanite to rhyolite, with a gap between 50 and 62 wt. $\% \mathrm{SiO}_{2}$. Mafic lavas display OIB features and HIMU mantle isotopic signature (Mbassa et al. 2012). The Pan-African plutonics consist of monzodiorites and a continuous granitic series extending from monzonites to granites. They mostly belong to an Itype suite displaying high-potassic calc-alkaline to shoshonitic features (Mbassa et al. 2016). Actually, apart from some alluvial surveys carried out by Dumort (1968) and Peronne (1969) indicating indices of gold, rutile, iron, and manganese, no intensive prospection activity has yet been carried on the studied area.

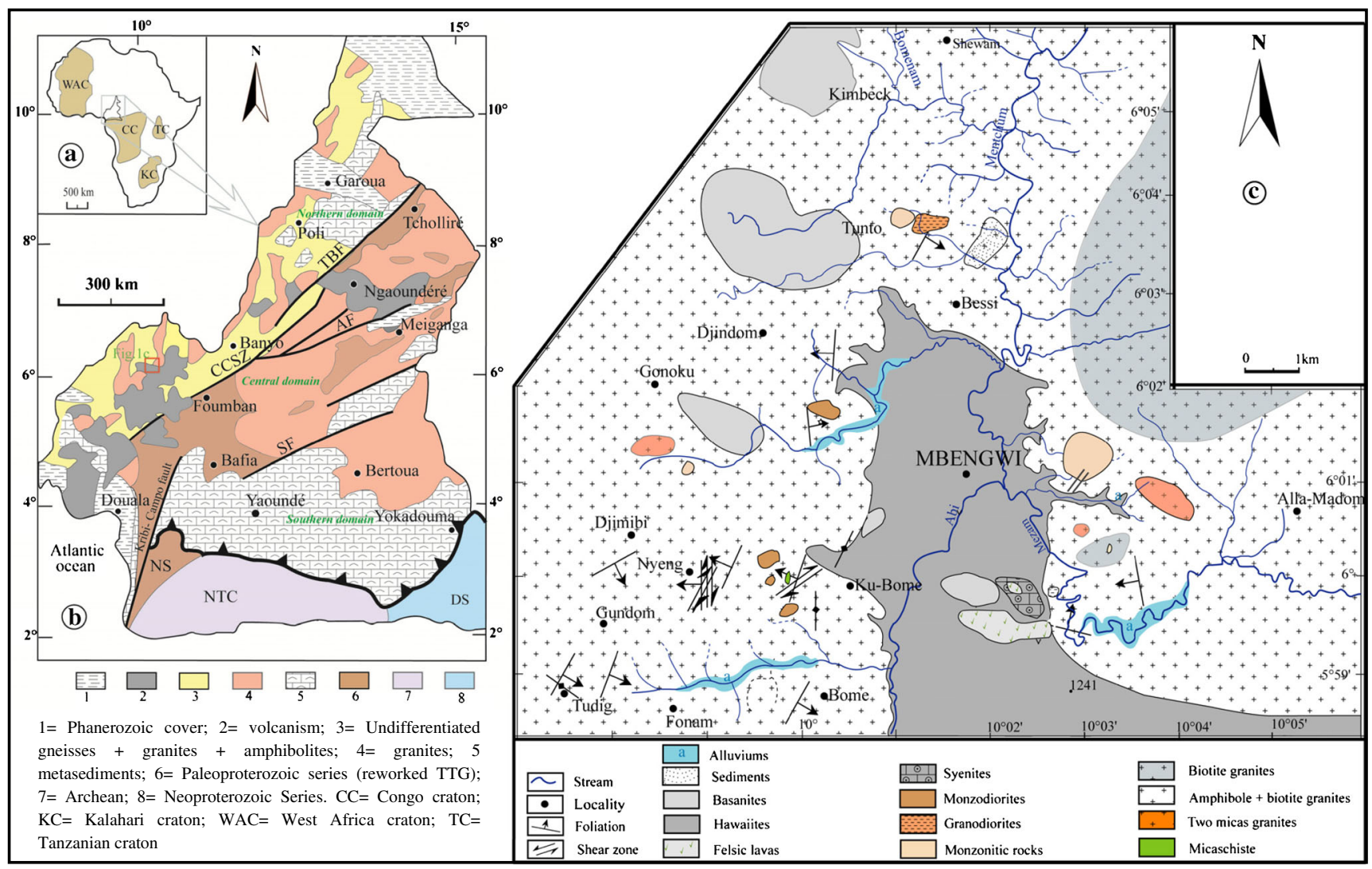

Fig. 1 Geological setting of the studied area. a Location of Cameroon in Africa. b Simplified geological map of Cameroon showing the main Pan-African domains. AF Adamawa fault, SF: Sanaga fault,
TBF: Tcholliré-Banyo fault, CCSZ: central Cameroon shear zone, NTC:Ntem complex, DS: Dja series, NS: Nyong series. c Geologic sketch map of the studied area 


\section{Analytical methods}

A set of 32 representative samples of Pan-African rocks from Mbengwi including granites, granodiorites, monzonites, quartz-monzonites, and monzodiorites were chosen for this study. Major elements were analyzed by ICP-OES and trace elements by ICP-MS, respectively, at the laboratories of École des mines de Saint-Etienne (France) and Geosciences Environnement Toulouse (GET-OMP, University of Toulouse 3, France). International geostandards were used. Weis and Frey (1991), Benoit et al. (1996), and Aries et al. (2000) describe analytical methods in details. The detection limits for trace elements range between $10^{-2} \mathrm{ppm}$ (REE) and $20 \mathrm{ppm}(\mathrm{Zr})$.

Mineral major element compositions were determined with a CAMECA SX 50, at the service of microanalysis and microscopy of Geosciences Environnement Toulouse (GETOMP, University of Toulouse 3, France). Analytical conditions were $15 \mathrm{kV}$ for the acceleration tension, and the beam size was $2 \times 2 \mu \mathrm{m}$ under 10 or $20 \eta \mathrm{A}$, according to resistance of mineral to the electronic beam. Acquisition times were $10 \mathrm{~s}$ for the peak and $5 \mathrm{~s}$ on both sides of the peak, for an analyzed volume of $5 \mu \mathrm{m}^{3} ; \mathrm{K} \alpha$ lines were used.

\section{Petrography and geochemistry}

Plutonics from Mbengwi consist of coarse-grained granitic rocks and fine-grained monzodiorites. Granitic rocks include monzonites, quartz-monzonites, granodiorites, and granites (biotite granites, amphibole-biotite granites, and two-mica granites). The monzodiorites $\left(\mathrm{An}_{27.2-44.1}\right)$ outcrop within granitoids as small subrounded or elongated enclaves. The leading mineral phase assemblage including quartz (Qtz), Kfeldspar, plagioclase, amphibole, and biotite is completed by muscovite in two-mica granites. The accessory phase includes ilmenite, magnetite, sphene, apatite, and zircon. Biotite (Bt) is locally transformed to chlorite or prehnite, amphibole to chlorite, epidote or calcite, and ilmenite to goethite.

Whole rock geochemical analysis for representative plutonic samples from Mbengwi including major and trace elements are listed in Table 1. The studied calc-alkaline plutonics are mainly volcanic-related, metaluminous to weakly peraluminous (Fig. 2a) and their $\mathrm{SiO}_{2}$ contents range between 48 and 77.9 wt.\%. Only one sample $\left(\mathrm{E}_{125}: \mathrm{A} / \mathrm{NK}=0.98\right)$ can be considered as peralkaline although it contains Mg-biotites. They are of I-type with high-K to shoshonitic affinities. However, one sample of two-mica granites has typical Stype features, suggesting either the sedimentary nature of the protolith or the assimilation of sedimentary xenoliths (Mbassa et al. 2016). The studied plutonics are strongly fractionated $\left((\mathrm{La} / \mathrm{Lu})_{N}=4.05-102.96\right)$ and characterized by LILE and LREE enrichment compared with HFSE and HREE respectively. They also display negative $\mathrm{Rb}, \mathrm{K}, \mathrm{Sr}, \mathrm{P}, \mathrm{Ti}$, Eu, and positive Th and La anomalies (Fig. 2b, c); such features are consistent with a subduction environment.

$\mathrm{The} \mathrm{Sr}$ and $\mathrm{Nd}$ isotopic compositions of these plutonics evidence the involvement of heterogeneous crustal materials including both the lower continental and oceanic crusts during the melting processes. The Mbengwi plutonics are then specific; since the other Pan-African high-K calc-alkaline plutons from western and central Cameroon are all melting products of the continental crust only (Mbassa et al. 2016).

\section{Discussion}

As it has been mentioned above, Mbengwi plutonics are predominantly of I-type and coexist with small outcrops of S-type rocks. According to Nédélec and Bouchez (2011), such granitoids are known to be enriched respectively in chalcophile $(\mathrm{Cu}, \mathrm{Ag}, \mathrm{Zn}, \mathrm{Ga} . .$.$) and lithophile (\mathrm{Sn}, \mathrm{W}, \mathrm{U}, \mathrm{Nb}, \mathrm{Ta}, \mathrm{Be}$, and $\mathrm{Li}$ ) elements. Thus, several geochemical indicators have been used to differentiate potential productive granitoids from barren ones. The comparison of the studied plutonics contents in some elements of metallogenic interest such as $\mathrm{Cu}, \mathrm{Sn}, \mathrm{Pb}$, $\mathrm{Th}$, and $\mathrm{Zn}$ with their Clarke as shown in Table 2 reveals that they possess interesting chemical enrichment clues. The results are discussed below.

\section{Sn and $W$ mineralization}

The degree and type of differentiation and oxidation state of the magma that formed granites are important to determine the potential and type of associated mineralization (Blevin 2003). The Mbengwi plutonics have $\mathrm{SiO}_{2}(48.11-77.90$ wt.\%) and $\mathrm{K}_{2} \mathrm{O}$ (1.65-7.21 wt.\%) contents in the range of Sn- and Wrelated granitoids, and $\mathrm{K} / \mathrm{Rb}$ ratios between 132 and 955 . They are mainly moderately evolved (Fig. 3a). Highly evolved granitoids, indicators of $\mathrm{Sn}, \mathrm{W}, \mathrm{U}, \mathrm{Li}, \mathrm{Be}$, and REE mineralizing potential, have $\mathrm{K} / \mathrm{Rb}$ ratios under 100 (Rossi et al. 2011), and Sn-related granitic rocks are predominantly of S-type (Govett and Atherden 1988). Consequently, the predominant I-type nature of the Mbengwi granitoids and their high $\mathrm{K} / \mathrm{Rb}$ ratios (132-955) do not favor high concentration of the above trace and rare earth elements. The Mbengwi plutonics display high $\mathrm{Sr}, \mathrm{Rb}$, and $\mathrm{Ba}$ contents in addition to $\mathrm{Sm} /$ $\mathrm{Eu}$ and $\mathrm{Rb} / \mathrm{Ba}$ ratios compared to related porphyry tin deposits (data from Lehmann and Mahawat 1989; Pei and Hong 1995) (Fig. 3b), meaning that the studied plutonics might not be fertile regarding tin mineralization. Otherwise, Karimpour and Bowes (1983) used diagrams such as $\mathrm{Rb} / \mathrm{Sr}$ and $\mathrm{Ce} / \mathrm{Yb}$ ratios versus color index $\left(\left[\mathrm{CI}=\left(\mathrm{SiO}_{2}+\mathrm{K}_{2} \mathrm{O}+\mathrm{Na}_{2} \mathrm{O}\right) /\right.\right.$ $(\mathrm{MgO}+\mathrm{CaO}+\mathrm{FeO})])$ to differentiate granitoids and identify their economic potential for tin, molybdenum, or copper (Fig. 4a, b). The Mbengwi granitoids when plotted in those 


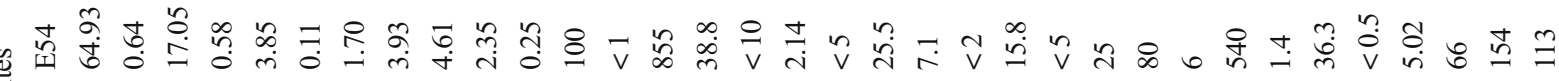
음

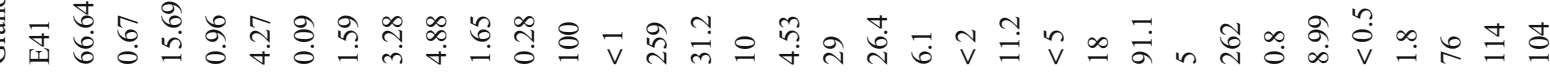

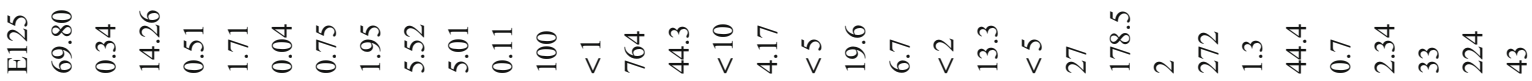

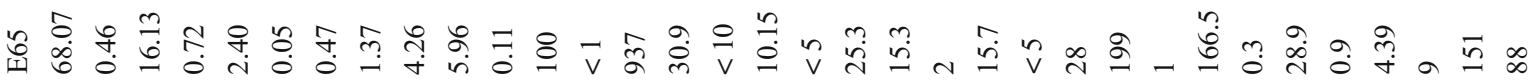

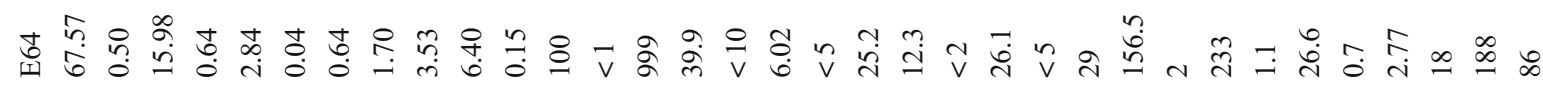

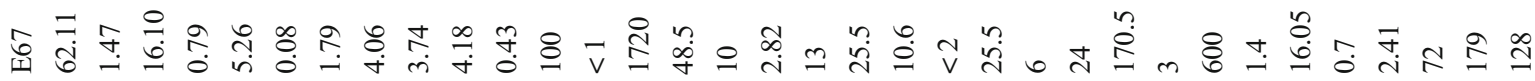

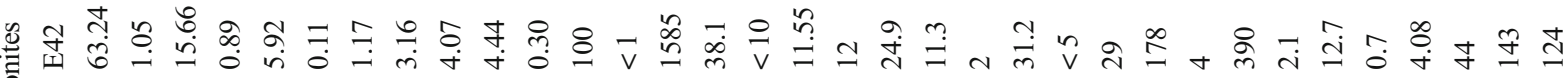

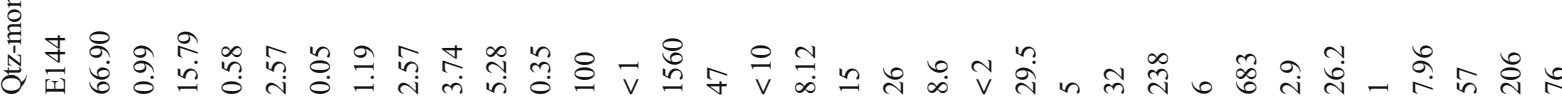

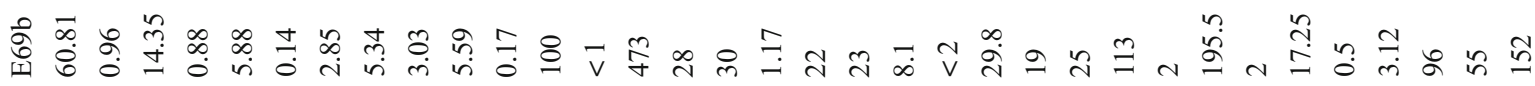
造

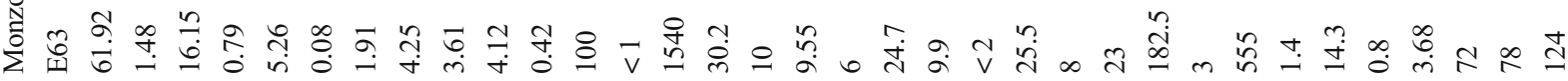

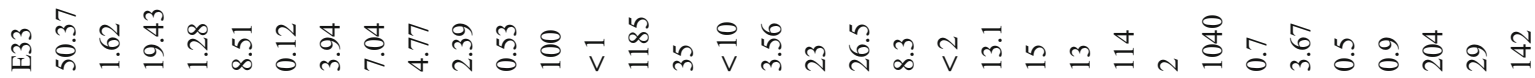

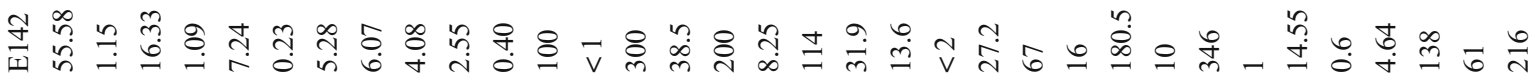

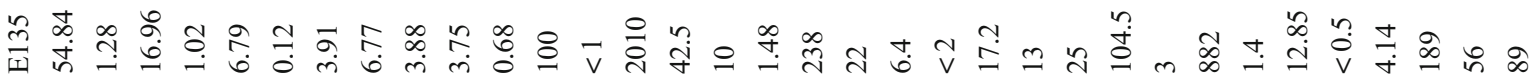

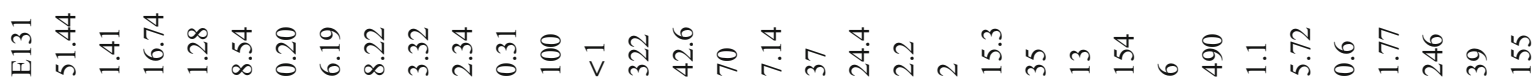

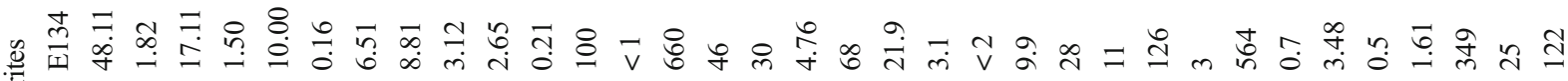
:

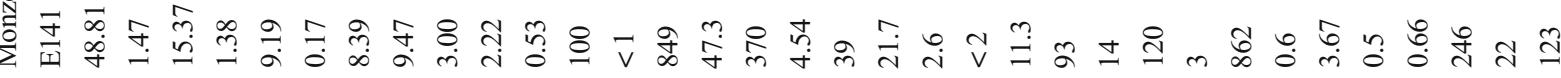

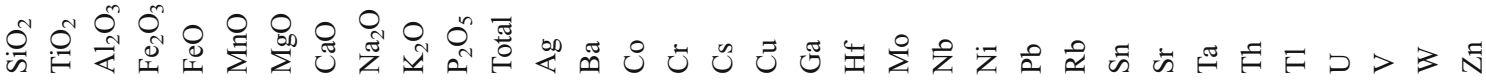




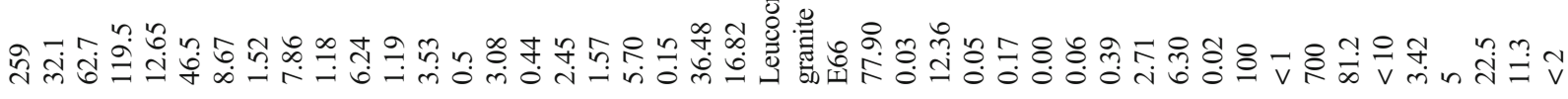

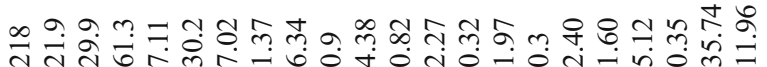

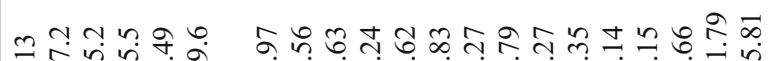

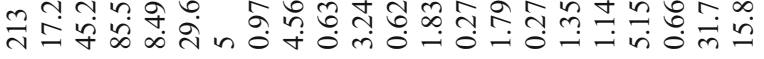

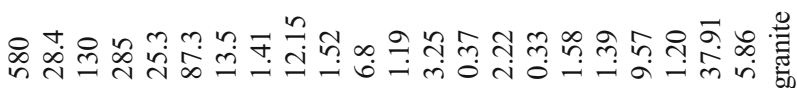

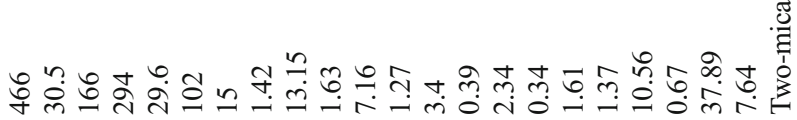

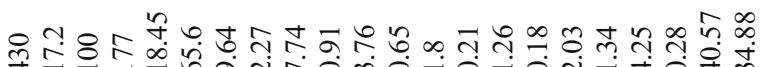

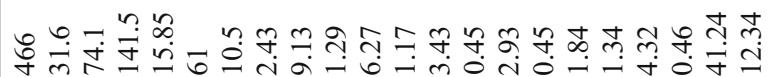

๓ ํำ

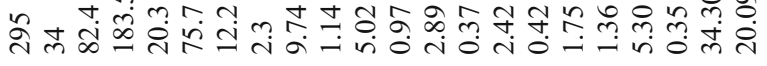

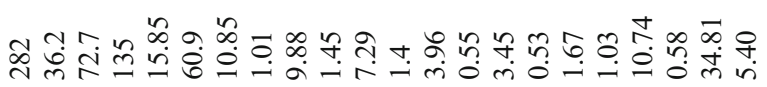

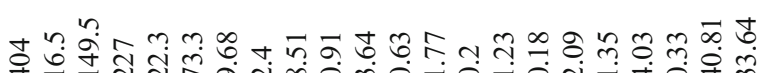

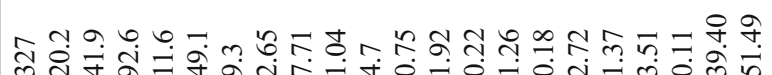

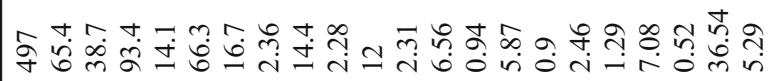

苟

๙ি

ț

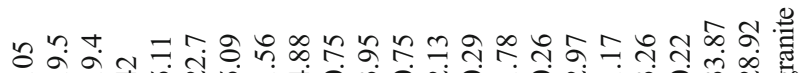

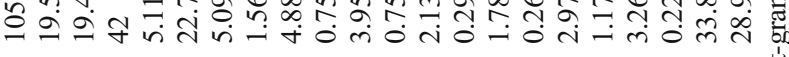

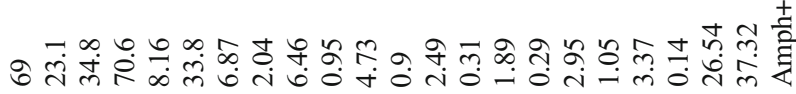

ฮั

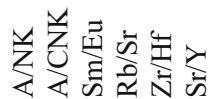

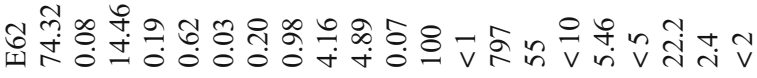

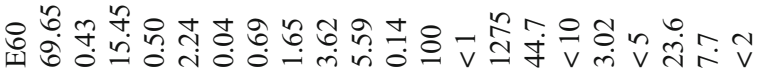

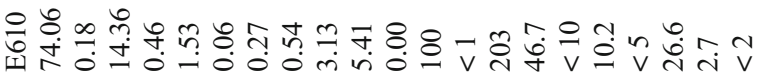

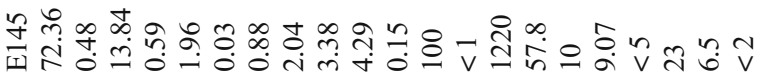

立芒

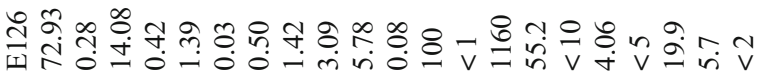

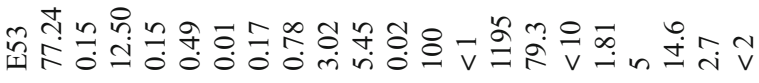

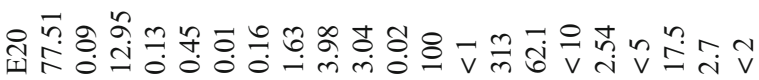

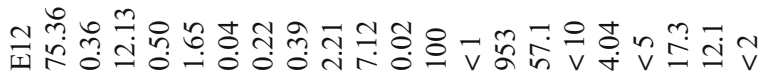

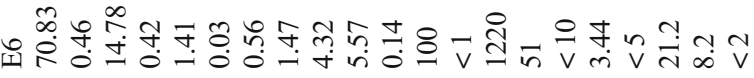

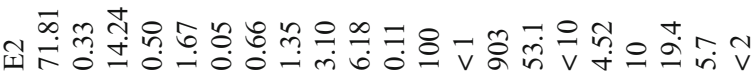

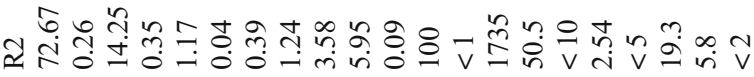

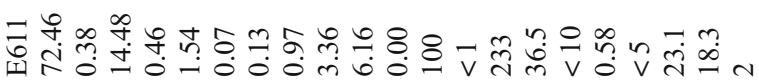

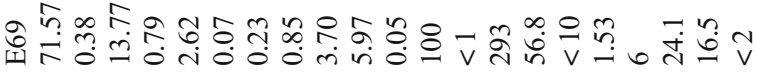

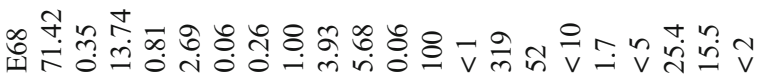




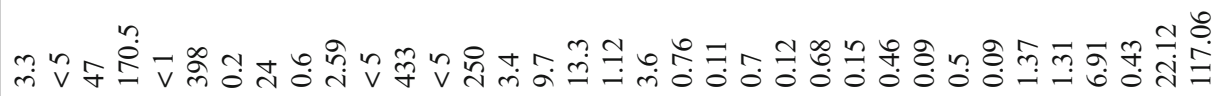

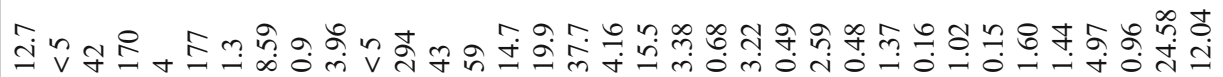

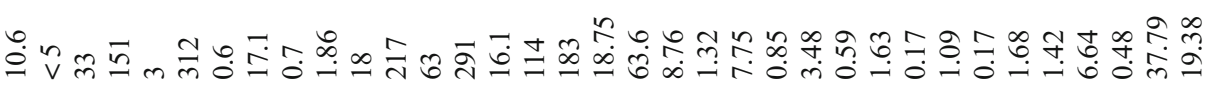

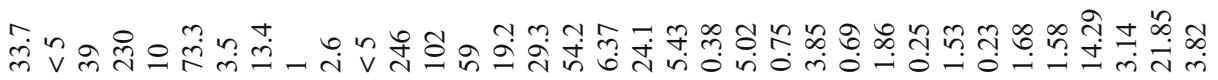

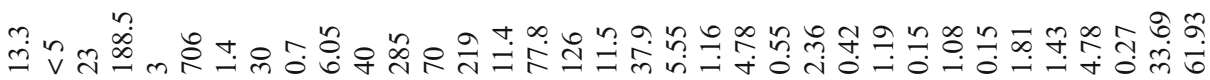
nै?

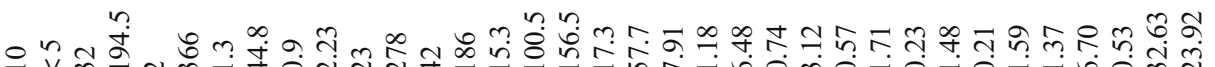

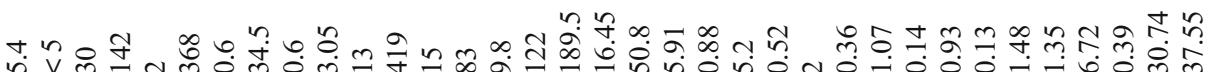
$+\infty$ त舫-

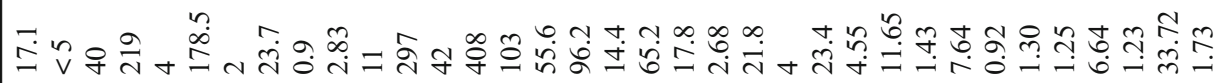

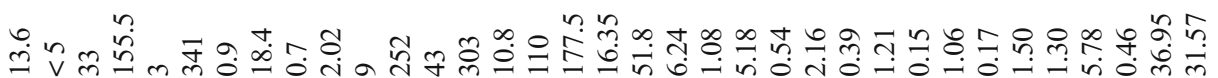

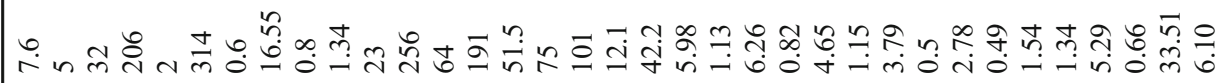

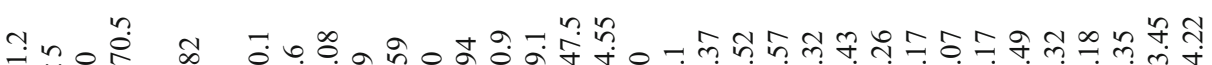

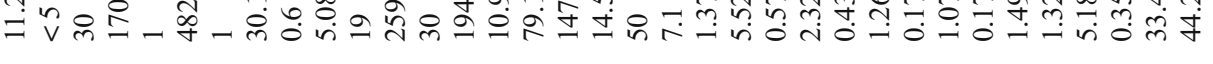

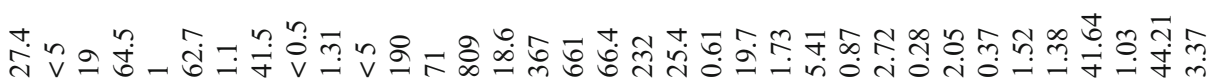

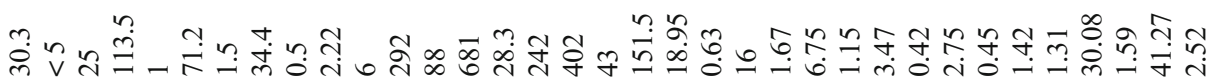

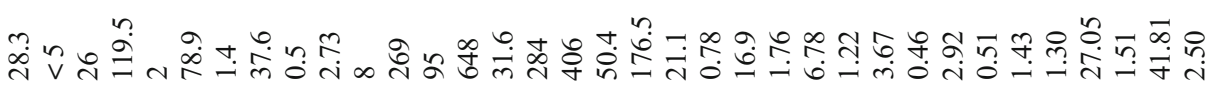

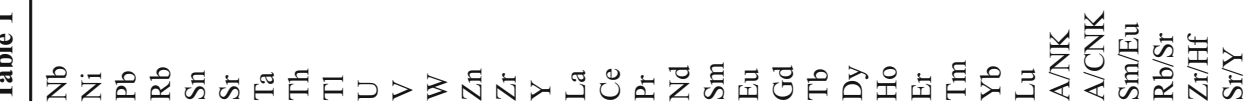


diagrams indicate that they remain unproductive in $\mathrm{Sn}$ and $\mathrm{Mo}$, and rather fertile regarding $\mathrm{Cu}$. Elsewhere, special minerals such as tourmaline and topaz are known to be symptomatic of tin (Sn) mineralization (Rozendaal and Bruwer 1995); therefore, the non-appearance of tourmaline and topaz in the studied rocks evidences that the mineralization of tin is unlikely. The high Sn content of some granites may be justified by the fact that as $\mathrm{Sn}$ is hosted by muscovite, its content will increase proportionally with the amount of muscovite during differentiation process (Neiva et al. 2002). Generally, granitic rocks hosting Sn, U, and W mineralization commonly have high phosphorus concentration (Ruiz et al. 2008). Furthermore, Bea et al. (1992) specified that $\mathrm{P}_{2} \mathrm{O}_{5}$ contents greater than $0.5 \mathrm{wt} . \%$ in rocks having more than $70 \mathrm{wt} . \% \mathrm{SiO}_{2}$ are good indicators of economic mineralization. Taking into consideration this last statement, we realize that in Mbengwi, only granites have $\mathrm{SiO}_{2}$ contents greater than $70 \mathrm{wt} . \%$ and their average $\mathrm{P}_{2} \mathrm{O}_{5}$ content is somewhat less than $0.5 \mathrm{wt} . \%$.

\section{Zn mineralization}

Wolfe (1977) and Lentz (1998) established a relation between the $\mathrm{SiO}_{2}$ content and the amount of $\mathrm{Zn}$ in granitoids. $\mathrm{Zn}$ amount is fixed $(\approx 85 \mathrm{ppm})$ for intermediate rocks, decreases linearly with increasing $\mathrm{SiO}_{2}$ in rocks having more than 60 wt.\% $\mathrm{SiO}_{2}$ and reaches $35 \mathrm{ppm}$ in rocks with $75 \mathrm{wt} . \% \mathrm{SiO}_{2}$. Almost all the studied rocks except the leucocratic granite $\left(\mathrm{E}_{66}\right)$ contain $\mathrm{Zn}$ with amount ranging from 15 to $216 \mathrm{ppm}$. On the other hand, Wolfe (1977) stated that all rocks containing more than $10 \mathrm{wt} . \%$ of total iron may be good targets in regional explorations of zinc, and therefore suggested the use of $\mathrm{SiO}_{2}$ vs. $\mathrm{Fe}$ and $\mathrm{SiO}_{2}$ vs. $\mathrm{Zn}$ discriminating diagrams to decipher the sterile or fertile nature of plutonics regarding $\mathrm{Zn}$ detection. These diagrams disclose that the Mbengwi granitic rock samples are mostly fertile with regard to zinc (Fig. 5a, b). In mineralogy, despite the non-occurrence in the studied area of $\mathrm{Zn}$-bearing mineral such as sphalerite known as major ore for $\mathrm{Zn}$, the fertile character of the Mbengwi

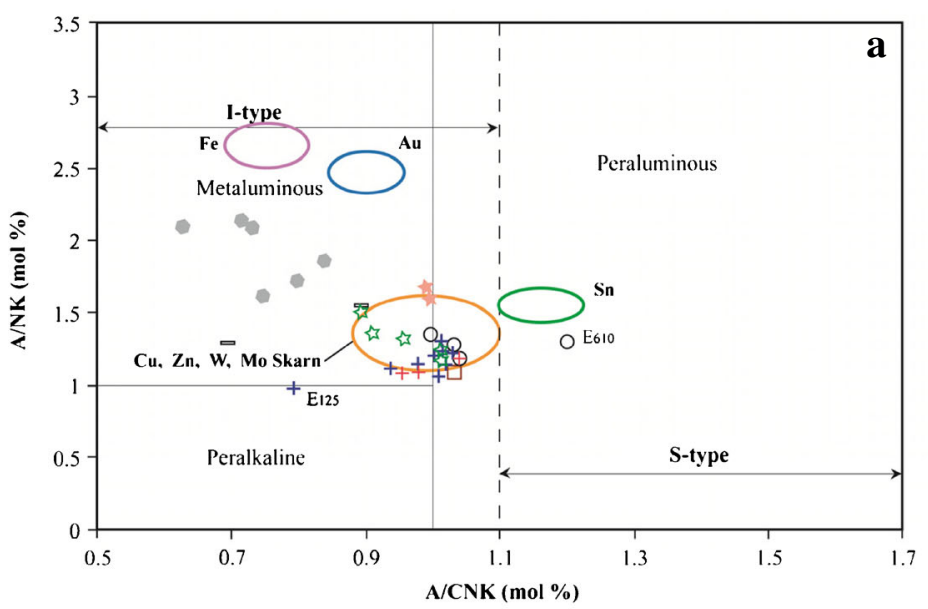

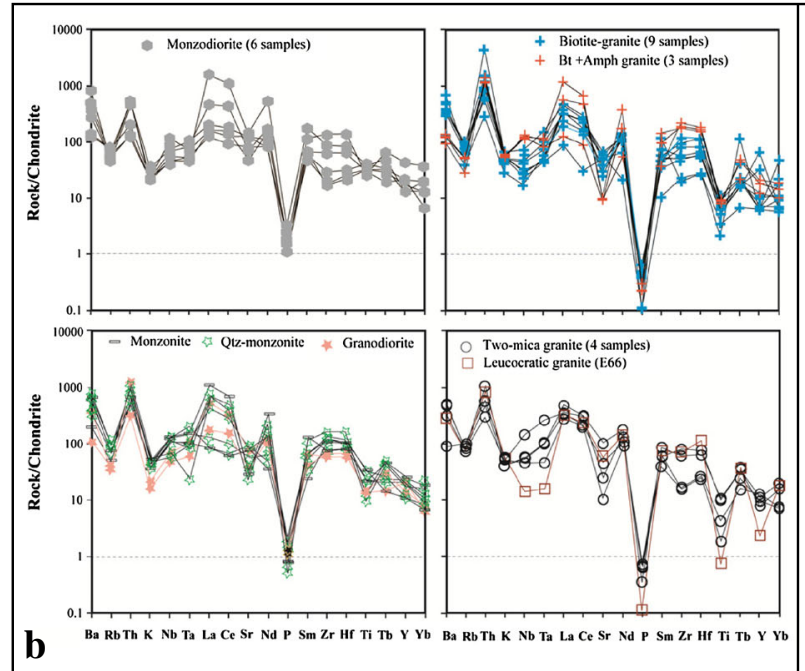

Fig. 2 a $\mathrm{A} / \mathrm{NK}$ vs. $\mathrm{A} / \mathrm{CNK}$ variation diagram of Maniar and Piccoli (1989) showing the mean composition of the Mbengwi plutonic rocks with related metals. The open circles with respective names are from

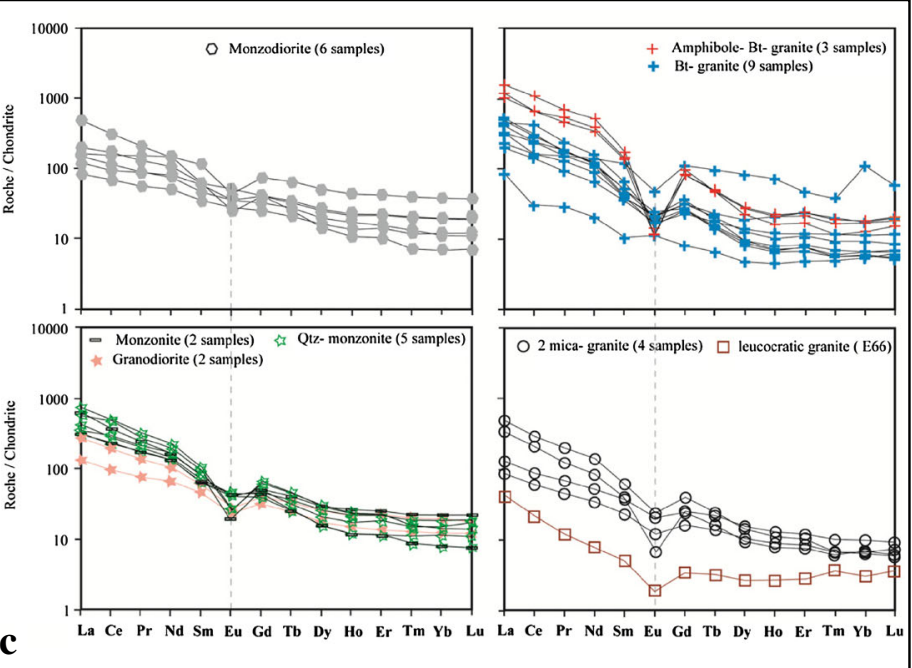

Meinert (1995). b Chondrite-normalized multi-element diagrams. c Chondrite normalized rare earth element diagrams for the studied rocks. Normalization value after McDonough and Sun (1995) 
Table 2 Comparison of contents of some elements from the Mbengwi plutonics with respect to their Clarke. The Clarke are from Wedepohl (1995)

\begin{tabular}{|c|c|c|c|c|}
\hline Element & $\begin{array}{l}\text { Amount within the } \\
\text { continental crust (ppm) }\end{array}$ & $\begin{array}{l}\text { Amount in the Mbengwi } \\
\text { plutonics (ppm) }\end{array}$ & Enriched rocks & $\begin{array}{l}\text { Rate of } \\
\text { enrichment }\end{array}$ \\
\hline $\mathrm{Cu}$ & 25 & $<5-238\left(\mathrm{E}_{135}\right)$ & Monzodiorites $\left(\mathrm{E}_{134}, \mathrm{E}_{135}, \mathrm{E}_{142}\right)$ & $2-9$ times \\
\hline $\mathrm{Sn}$ & 2 & $<1-10\left(\mathrm{E}_{142} . \mathrm{E}_{610}\right)$ & $\begin{array}{l}\text { Monzodiorites }\left(\mathrm{E}_{131}, \mathrm{E}_{142}\right) . \\
\text { Quartz monzonites }\left(\mathrm{E}_{42}, \mathrm{E}_{144}\right) \text {. } \\
\text { Granodiorites. Bt-granite }\left(\mathrm{E}_{12}\right) \text {. } \\
\text { Two-mica granites }\left(\mathrm{E}_{62} . \mathrm{E}_{610}\right)\end{array}$ & $2-5$ times \\
\hline $\mathrm{Pb}$ & 15 & $11-47\left(\mathrm{E}_{66}\right)$ & $\begin{array}{l}\text { Almost all Bt-granites. Two-mica } \\
\text { granites and leucocratic granite }\end{array}$ & $2-3$ times \\
\hline Th & 9 & $3.48-126\left(\mathrm{E}_{129}\right)$ & $\begin{array}{l}\text { Quartz monzonites except } \mathrm{E}_{42} \text {. } \\
\text { Granodiorite }\left(\mathrm{E}_{54}\right) \text {. } \\
\text { Amph+Bt-granites. Almost all } \\
\text { biotite-granites two-mica } \\
\text { granite }\left(\mathrm{E}_{145}\right)\end{array}$ & $2-14$ times \\
\hline $\mathrm{Zn}$ & 65 & $<5-216\left(\mathrm{E}_{142}\right)$ & $\begin{array}{l}\text { Almost all monzodiorite except } \mathrm{E}_{135} \text {. } \\
\text { All monzonites and some } \\
\text { quartz monzonites }\left(\mathrm{E}_{42}, \mathrm{E}_{67}\right)\end{array}$ & $2-3$ times \\
\hline
\end{tabular}

granitoids regarding $\mathrm{Zn}$ is expressed by a significant occurrence of this metal in some biotites, magnetites, chlorites, and calcites. Chlorites and biotites hosting the highest amounts of $\mathrm{ZnO}(>$ 0.3 wt.\%) are respectively ripidolite and Fe- or Mg-biotites. Those minerals displaying the highest amount of $\mathrm{ZnO}$ mostly occur in quartz monzonites $\left(\mathrm{E}_{144}, \mathrm{E}_{64}\right)$, granodiorites $\left(\mathrm{E}_{41}, \mathrm{E}_{54}\right)$, and in a two-mica granite $\left(\mathrm{E}_{60}\right)$. The estimation of the proximity of unusual $\mathrm{Zn}$ concentration and accordingly potential $\mathrm{Zn}$ mineralization at surface in semi-arid environments can be made possible using an index based on $\mathrm{Zn} / \mathrm{Mn}$ ratios in $\mathrm{Fe}-\mathrm{Mn}$ crusts of Spinks et al. (2017). According to this index, values of $\mathrm{Zn} / \mathrm{Mn}$ ratios above 0.006 are indicative of the proximity of a probable metal source. Apart from the leucocratic sample $\left(\mathrm{E}_{66}\right)$ containing no $\mathrm{Mn}$, all the studied samples have $\mathrm{Zn} / \mathrm{Mn}$ ratios $(0.072-0.226)$ higher than $6 \times 10^{-3}$; therefore, samples which are assigned fertile would be mineralized very close to the surface.

\section{Cu mineralization}

Copper and zinc behave differently during fractional crystallization process, although their chemical properties are close. Copper is mostly founded in chalcopyrite while zinc substitutes iron in ferromagnesian silicates (Bahajroy and Taki 2014). Usually, copper mineralization are found either above subduction zones in magmatic arcs or in post-collisional settings developed at the end of the subduction (Sillitoe 2010; Richards 2011). In both environments, the discrimination between the productive and the barren rocks regarding copper is routinely based on whole rock geochemistry (Baldwin and Pearce 1982; Asadi et al. 2014; Zarasvandi et al. 2015). The ore-forming granitoids display $\mathrm{Sr} / \mathrm{Y}$ ratio values higher than 35, low HFSE contents, and absence of pronounced negative $\mathrm{Eu}$ anomalies (Shafiei et al. 2009; Hou et al. 2011; Richards et al. 2012;
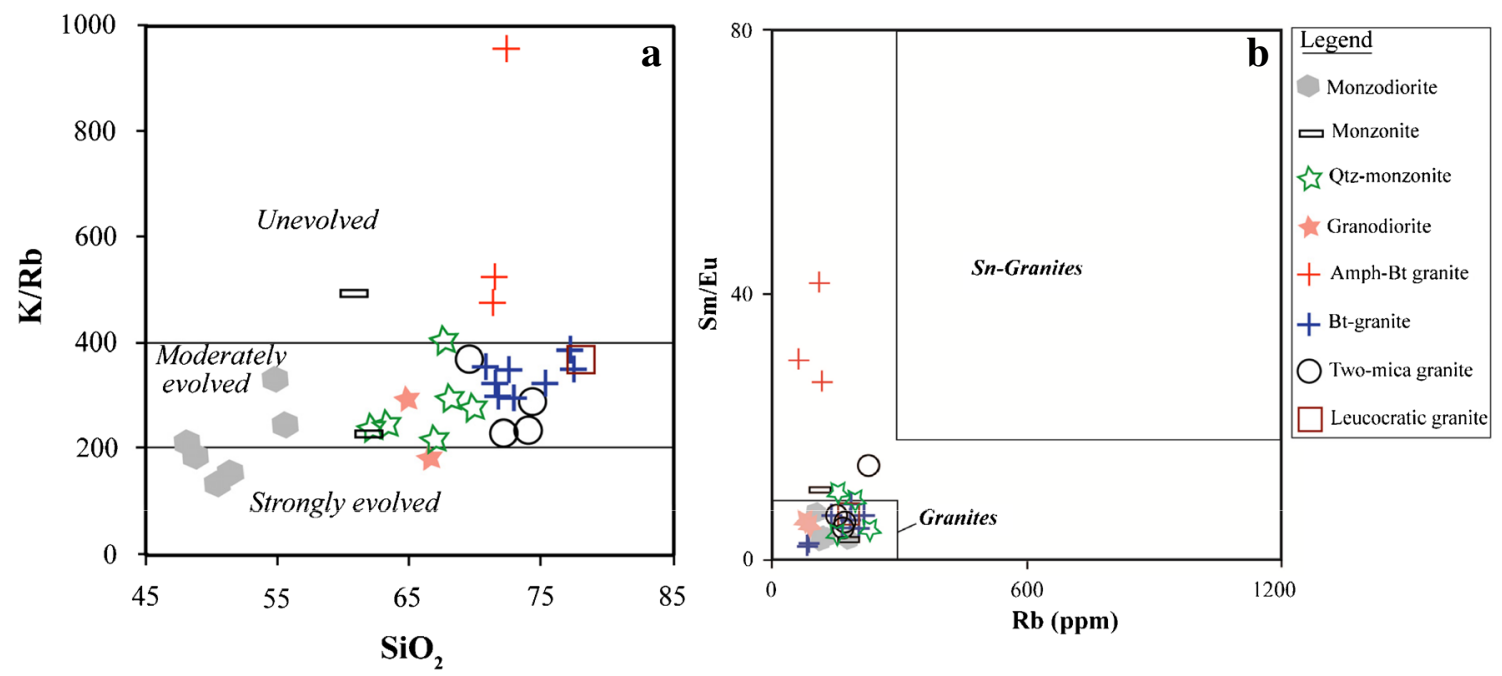

Fig.3 a Plot of K/Rb vs. $\mathrm{SiO}_{2}$ (wt.\%) (Blevin 2003). Most studied samples are semi-evolved. b Sm/Eu vs. Rb (ppm) diagram discriminating tin-bearing granites from barren ones (Karimpour and Bowes 1983) 

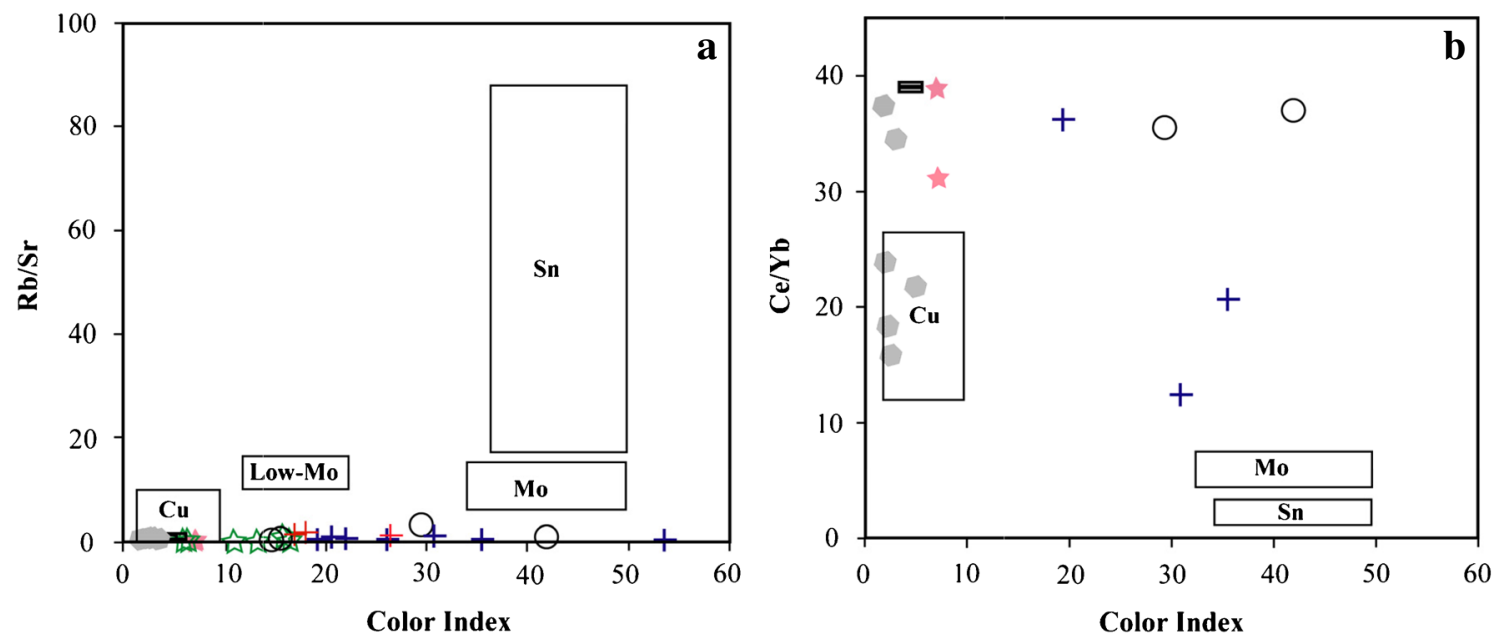

Fig. 4 Discrimination of source rock diagrams of $\mathrm{Cu}$, Sn, and Mo porphyry deposits using a color index and ratios of $\mathbf{a} \mathrm{Rb} / \mathrm{Sr}$ and $\mathbf{b} \mathrm{Ce} / \mathrm{Yb}(\mathrm{Karimpour}$ 1999) and a plot of the study area's samples

Gao et al. 2013; Ahmadian et al. 2015; Wu et al. 2016). The Mbengwi syn- to post-collisional plutonics mainly display lower $\mathrm{Sr} / \mathrm{Y}$ ratios (with very few samples having $\mathrm{Sr} / \mathrm{Y}>3$, low HFSE contents (Table 1), and overall negative anomaly in $\mathrm{Eu}$ ).

The use of $\mathrm{Sr} / \mathrm{Y}$ vs. $\mathrm{SiO}_{2}$ and $\mathrm{Al}_{2} \mathrm{O}_{3} / \mathrm{TiO}_{2}$ vs. $\mathrm{SiO}_{2}$ discriminating diagrams of Loucks (2014) (Fig. 6a, b) reveals that the composition of the Mbengwi plutonics overlaps both barren and productive areas. As shown in Fig. 6a, some granite samples (Bt-granite, two-mica granite, and leucocratic granite) are fertile while other plutonics are unproductive. The majority of samples are relatively barren regarding $\mathrm{Cu}$ deposits (Fig. 6b).

The $\mathrm{Y}$ versus $\mathrm{MnO}$ diagram of Baldwin and Pearce (1982) points out that the Mbengwi plutonics vary from barren to sub-productive and very few fertile granitoids (Fig. 7). Another discriminating diagram (Fig. 2a) also shows a productive nature for the Mbengwi calc-alkaline I-type granitoids regarding $\mathrm{Cu}$ and skarn ore deposits.

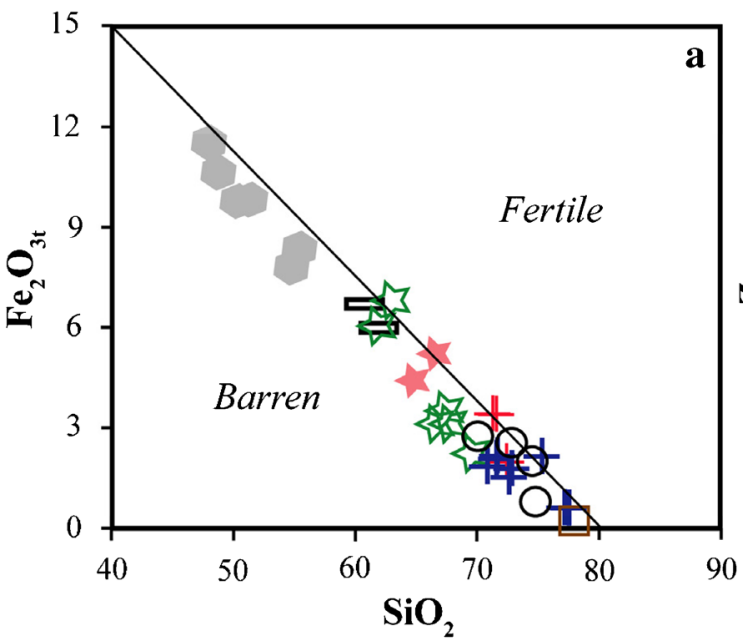

In order to identify if the magma could release or not hydrothermal phase, Bea et al. (2006) used $\mathrm{Zr} / \mathrm{Hf}$ ratio as index; when $\mathrm{Zr} / \mathrm{Hf}<20$, magmatic hydrothermal alteration occurred and mineralization processes are favored, and once $\mathrm{Zr} / \mathrm{Hf}>20$, this suggests that there was no hydrothermal alteration. The Mbengwi plutonics $\mathrm{Zr} / \mathrm{Hf}$ ratio ranges from 21.85 to 44.21 , meaning that they have not undergone magmatic hydrothermal alteration. Although some of the previous diagrams evidenced the productive character of the Mbengwi granitoids, their overall negative Eu anomaly (Fig. 2c) is symptomatic of their low potential to be hosting massive $\mathrm{Cu}$ deposits.

\section{Skarn mineralization}

Generally, skarn mineralizations are often associated either with metaluminous to slightly perluminous rocks or with calc-alkaline granitoids (Meinert 1995) as shown in Figs. 2a

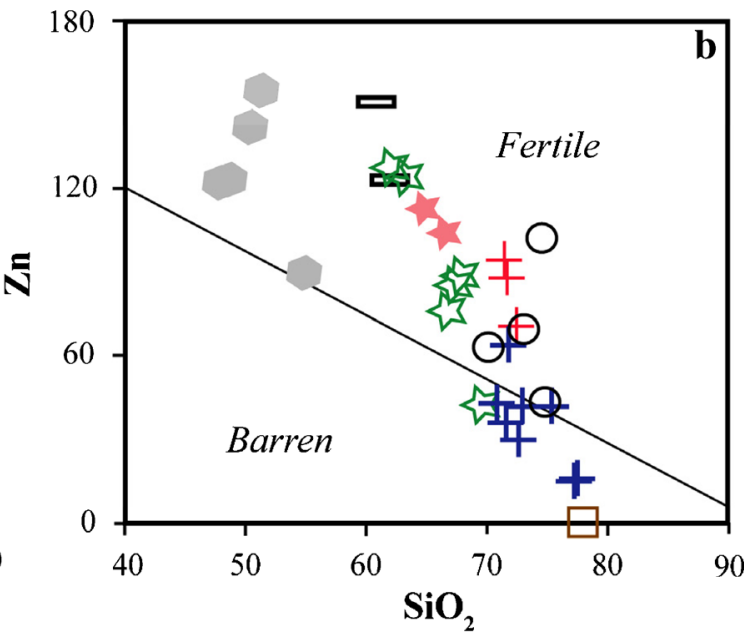

Fig. 5 Representation of the composition of Mbengwi granitoids in a $\mathrm{Fe}_{2} \mathrm{O}_{3} \mathrm{t}$ (wt.\%) and $\mathbf{b} \mathrm{Zn}$ (ppm) vs. $\mathrm{SiO}_{2}$ (wt.\%) of Wolfe (1977) discriminating barren and fertile granites 

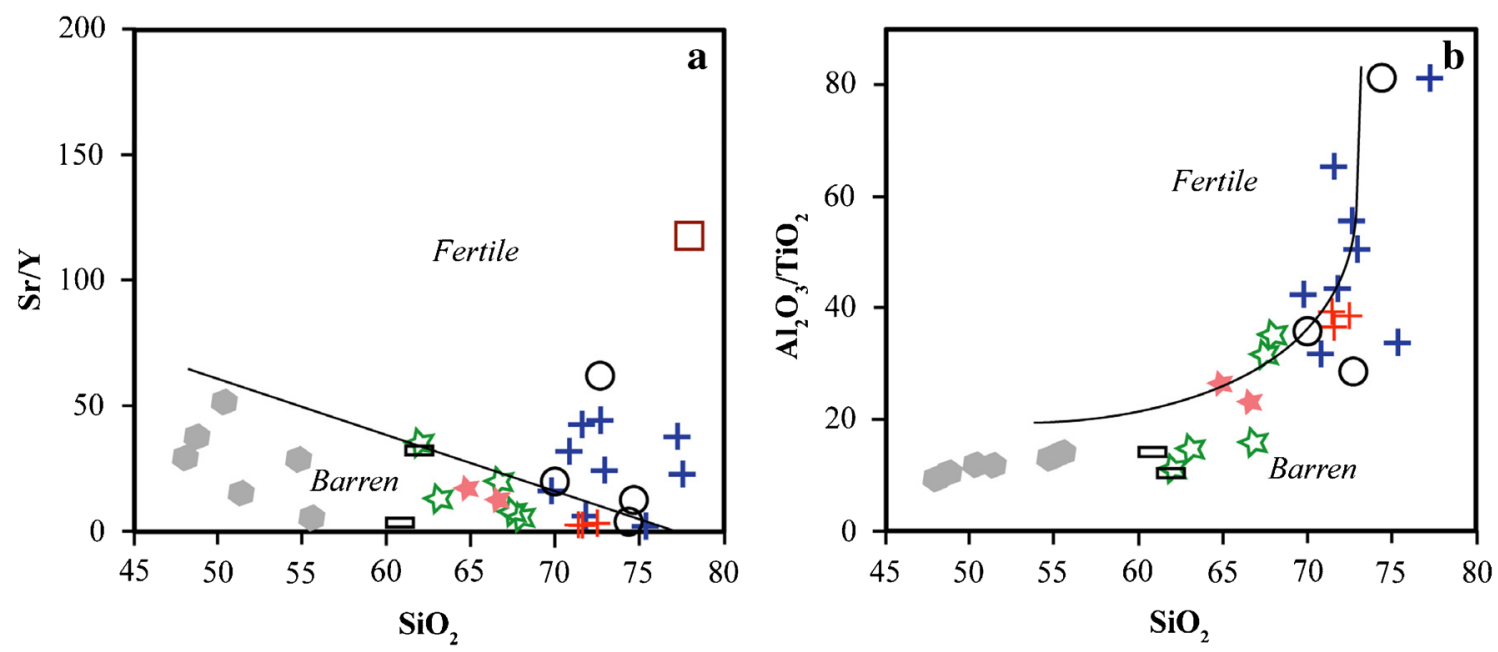

Fig. 6 Plot of whole rock chemistry of the Mbengwi granitoids on discriminating diagrams of Loucks (2014). a Sr/Yvs. $\mathrm{SiO}_{2}$ (wt.\%) diagram. b $\mathrm{Al}_{2} \mathrm{O}_{3} /$ $\mathrm{TiO}_{2}$ vs. $\mathrm{SiO}_{2}$ (wt.\%)

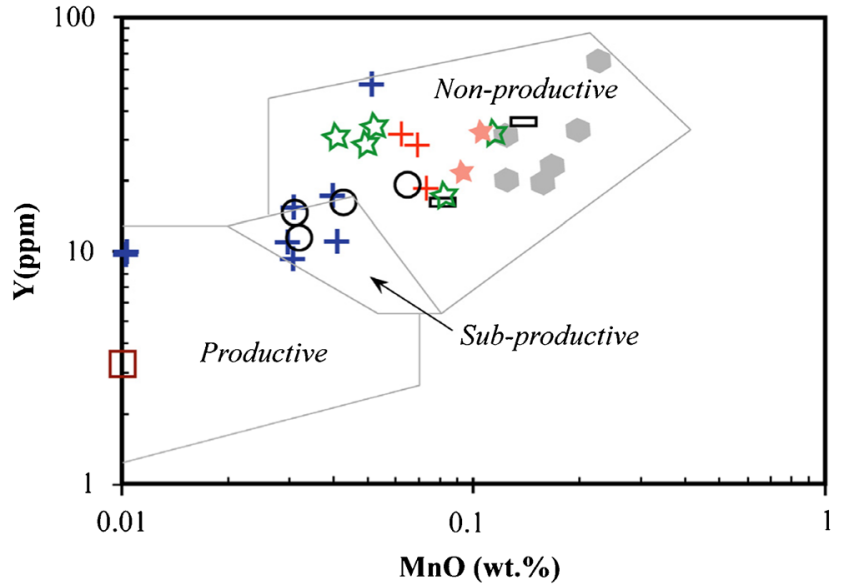

Fig. 7 Whole rock Y vs. MnO diagram of Baldwin and Pearce (1982) for the Mbengwi granitoids

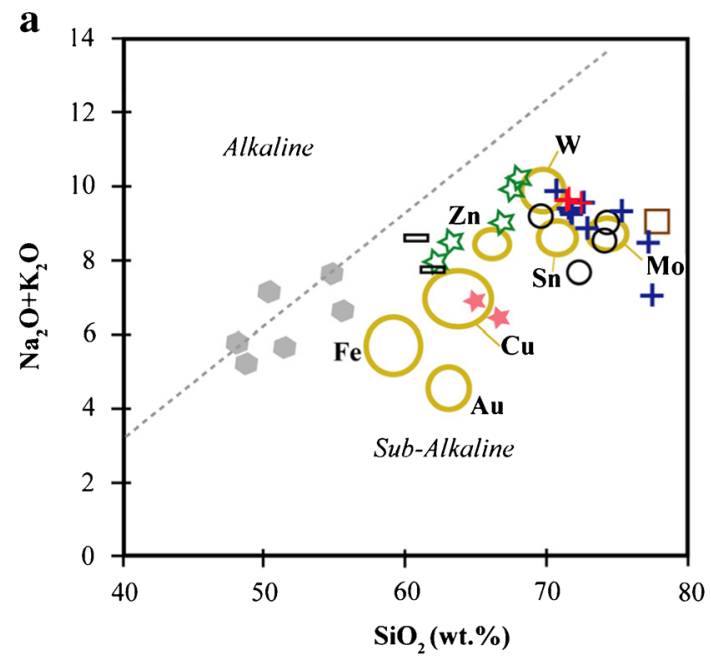

Fig. 8 Plotting of the Mbengwi granitoids composition together with the mean composition of various mineralized granitoids with related metals (of which the names are indicated) are from Meinert (1995) in $\mathbf{a} \mathrm{K}_{2} \mathrm{O}+$ and 8 , respectively. The projection of the studied plutonics in the A/CNK vs. A/NK diagram (Fig. 2a) reveals that compositions of some granitoids are essentially comparable to calcalkaline granitoids associated with $\mathrm{Cu}, \mathrm{Zn}, \mathrm{W}$, and Mo skarn. Monzodiorites and few intermediate rocks (monzonites, one Qtz-monzonite, and a granodiorite sample) overlap $\mathrm{Fe}$ and $\mathrm{Cu}$ skarn granitoids fields. In the $\left(\mathrm{Na}_{2} \mathrm{O}+\mathrm{K}_{2} \mathrm{O}\right)$ versus $\mathrm{SiO}_{2}$ diagram, the intermediate phases of the Mbengwi granitic rocks remain close to $\mathrm{Zn}$ and $\mathrm{Cu}$ skarn-related granitoids (Fig. 8a). Plotting of the studied rocks in the AFM diagram reveals that their compositions seem to be similar to those of granitoids associated with all skarn types (Fig. 8b), although this diagram indicates that compositions of the intermediate phases are alike to magmatic districts related to $\mathrm{Zn}$ and $\mathrm{Cu}$ mineralization. Using the $\mathrm{Nb}$ versus $\mathrm{Y}$ and $\mathrm{Rb}$ versus $(\mathrm{Y}+\mathrm{Nb})$ discriminative diagrams, the compositions of the Mbengwi granitoids

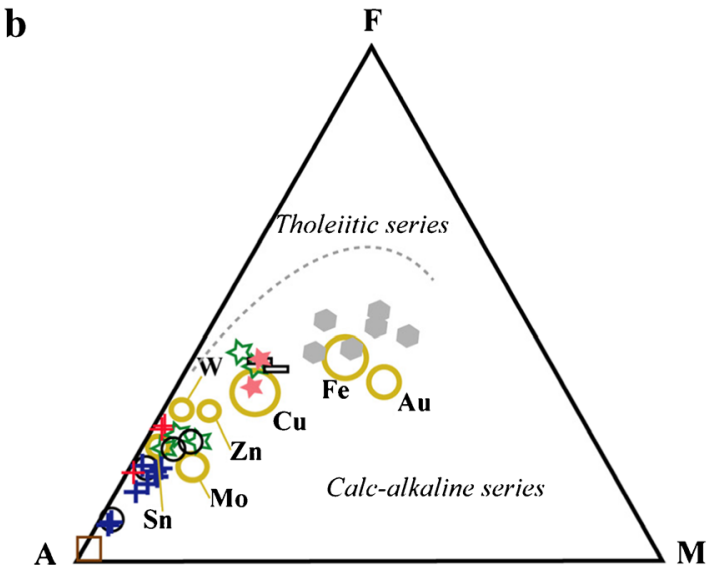

$\mathrm{Na}_{2} \mathrm{O}$ (wt.\%) vs. $\mathrm{SiO}_{2}$ (wt.\%) of Rickwood (1989) and b AFM diagram of Irvine \& Baragar (1971) 

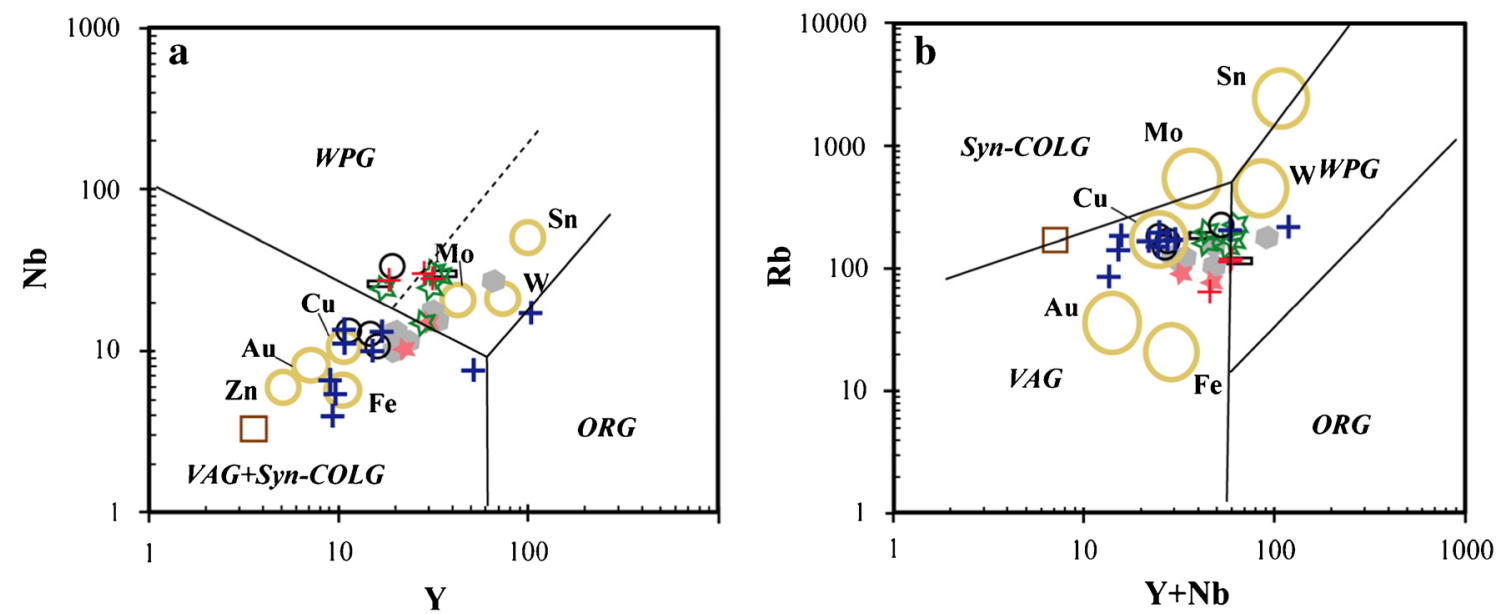

Fig.9 a, b Nb vs. Y and Rb vs. (Y + Nb) diagrams (Pearce et al. 1984; see also Förster et al. 1997); ORG = ocean-ridge granites; syn-COLG = syncollisional granites; $\mathrm{VAG}=$ volcanic arc granites; $\mathrm{WPG}=$ within-plate granites

plot nearby $\mathrm{Cu}, \mathrm{Fe}, \mathrm{Au}, \mathrm{Mo}, \mathrm{W}$, and $\mathrm{Zn}$ skarn-related granitoids (Fig. 9). However, it should be noticed that samples plotting within the skarn-related granitoids domain in Fig. 2 are not necessarily the same exhibiting high contents in $\mathrm{Cu}, \mathrm{Pb}$, $\mathrm{Th}$, and $\mathrm{Zn}$. The most widespread skarn mineral observed in the studied sample is pyrite (not analyzed). This mineral occurs as disseminated small grains.

\section{Thorium mineralization}

Th mineralization occurs in the upper continental crust, particularly in placers, granitic rocks, or veins. The determination of the Th mineralizing potential and consequently the discrimination between unproductive and mineralized granitic rocks from Mbengwi was based on the analysis of their contents in $\mathrm{P}$, followed by the use of the $\mathrm{P}_{2} \mathrm{O}_{5} * 100 / \mathrm{Th}$ vs. $\mathrm{B}(\mathrm{B}=\mathrm{Ti}+$ $\mathrm{Fe}+\mathrm{Mg}$ ) diagram in accordance with Scheepers (2000).

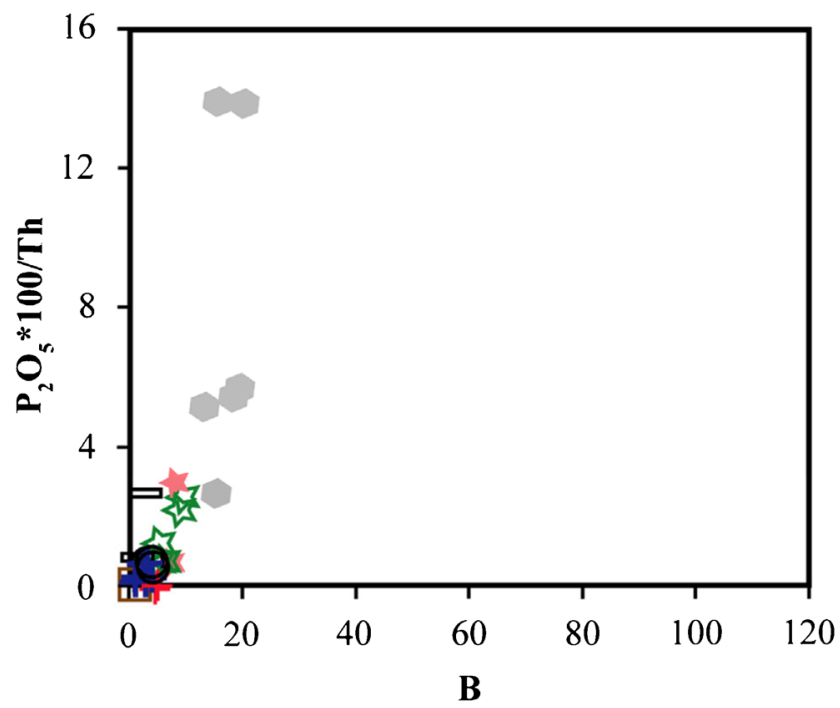

Fig. 10 Plots $\mathrm{P}_{2} \mathrm{O}_{5} * 100 /$ Th versus $\mathrm{B}(\mathrm{B}=\mathrm{Ti}+\mathrm{Fe}+\mathrm{Mg})$ for the Mbengwi granitoids
According to the previous author, Th-mineralized granitic rocks are particularly enriched in $\mathrm{P} / \mathrm{Th}$ and their composition trend in the $\mathrm{P}_{2} \mathrm{O}_{5} * 100 /$ Th vs. B diagram is nearly parallel to the $\mathrm{Y}$ axis. The use of this diagram for the studied granitic rocks (Fig. 10) reveals that the general trend is almost vertical and that monzodiorites and monzonites are almost parallel to the $\mathrm{Y}$ axis and can therefore be considered as mineralized or potentially mineralized.

\section{Conclusions}

The calc-alkaline affinity alongside the I-type nature and the range of $\mathrm{Sr} / \mathrm{Y}$ ratios of the Mbengwi granitoids evidence that their parental magmas particularly those of granites are likely fertile for $\mathrm{Cu}$ mineralization, related skarn, and for some metals, epithermal deposits. Nevertheless, they have not experienced post-magmatic hydrothermal activity required for $\mathrm{Sn}, \mathrm{U}, \mathrm{W}$, or Ta mineralization, given that they are moderately differentiated and have high $\mathrm{K} / \mathrm{Rb}$ ratios.

Several geochemical criteria such as color index, $\mathrm{Rb} / \mathrm{Sr}$, $\mathrm{Ce} / \mathrm{Yb}, \mathrm{Sm} / \mathrm{Eu}$, or $\mathrm{Rb} / \mathrm{Ba}$ ratios in addition to the behavior of $\mathrm{Rb}, \mathrm{Ba}$, and $\mathrm{Sr}$ disclose the barren nature of the Mbengwi granitoids regarding Sn, and Mo; though they might be rather productive concerning $\mathrm{Cu}$ and mainly fertile regarding $\mathrm{Zn}$, although we have not yet really observed minerals bearing those elements.

Acknowledgements We are thankful to the French Ministry of Foreign Affairs for the three stays of a total duration of 12 months, awarded to BJ Mbassa, as part of a doctoral scholarship in France, EGIDE and GETUMR 5563-CNRS for accommodation and analytical facilities. The coauthors also wish to dedicate this work to Junior Désiré Nolla, who died after a short illness on July 20, 2017. We mourn the loss of a human being of both exceptional qualities and a promising colleague. We are grateful to anonymous reviewer and the Editor-in-Chief Abdullah M. Al-Amri for the constructive reviews and insightful comments. 


\section{References}

Ahmadian J, Sarjoughian F, Lentz D, Esna-Ashari A, Murata M, Ozawa $\mathrm{H}$ (2015) Eocene K-rich adakitic rocks in the Central Iran: implications for evaluating its $\mathrm{Cu}-\mathrm{Au}-\mathrm{Mo}$ metallogenic potential. Ore $\mathrm{Geol}$ Rev 72:323-342

Aries S, Valladon M, Polvé M, Dupré B (2000) A routine method for oxide and hydroxide interference corrections in ICP-MS chemical analyses of environmental and geological samples. Geostand Newslett 24:19-31

Asadi A, Moore F, Zarasvandi A (2014) Discriminating productive and barren porphyry copper deposits in the southeastern part of the central Iranian volcano-plutonic belt, Kerman region, Iran: a review. Earth-Sci Rev 138:25-46

Bahajroy M, Taki S (2014) Study of the mineralization potential of the intrusives around Valis (Tarom-Iran). Earth Sci Res J 18:123-129

Baldwin JA, Pearce JA (1982) Discrimination of productive and nonproductive porphyritic intrusions in the Chilean Andes. Econ Geol 77:664-674

Bea F, Fershtater G, Corretge LG (1992) The geochemistry of P in granitic rocks and the effect of aluminium. Lithos 29:43-56

Bea F, Montero P, Ortega M (2006) A LA-ICP-MS evaluation of $\mathrm{Zr}$ reservoirs in common crustal rocks: implications for $\mathrm{Zr}$ and Hf geochemistry, and zircon forming processes. Can Mineral 44:693-714

Benoit M, Polvé M, Ceuleneer G (1996) Trace element and isotopic characterization of mafic cumulates in a fossil mantle diaper (Oman ophiolite). Chem Geol 134:199-214

Blevin P (2003) Metallogeny of granitic rocks. In: Magmas to mineralization. Blevin $\mathrm{P}$ et al. (eds). The Ishihara symp, pp 1-4

Djouka-Fonkwé ML, Schulz B, Schüssler U, Tchouankoué J-P, Nzolang C (2008) Geochemistry of the Bafoussam Pan-African I-and S-type granitoids in western Cameroon. J Afr Earth Sci 50:148-167

Dumort JC (1968) Carte géologique de reconnaissance du Cameroun à l'échelle du 1/500000, coupure Douala-Ouest avec notice explicative. Bulletin de la direction de géologie et des mines, Cameroun

Eugster HP (1985) Granites and hydrothermal ore deposits: a geochemical framework. Mineral Mag 49:7-23

Förster HJ, Tischendorf G, Trumbull RB (1997) An evaluation of the Rb vs. $(\mathrm{Y}+\mathrm{Nb})$ discrimination diagram to infer tectonic setting of silicic igneous rocks. Lithos 40:261-293

Gao Y, Santosh M, Wei R, Ma G, Chen Z, Wu J (2013) Origin of high Sr/ Y magmas from the northern Taihang Mountains: implications for Mesozoic porphyry copper mineralization in the North China Craton. J Asian Earth Sci 78:143-159

Ghodsi MR, Boomeri M, Bagheri S, Lentz D, Ishiyama D (2016) Metallogeny and mineralization potential of the Bazman Granitoids, SE Iran. Resour Geol 66(3):286-302

Govett GJS, Atherden PR (1988) Application of rock geochemistry to productive plutons and volcanic sequences. Geochem Explor 30: 223-242

Hou Z, Zhang H, Pan X, Yang Z (2011) Porphyry Cu (-Mo-Au) deposits related to melting of thickened mafic lower crust: examples from the eastern Tethyan metallogenic domains. Ore Geol Rev 3:21-45

Irvine TN, Baragar WRA (1971) A guide to the chemical classification of the common volcanic rocks. Can J Earth Sci 8:523-548

Karimpour MH (1999) Application of $\mathrm{Sm} / \mathrm{Eu}, \mathrm{Rb} / \mathrm{Sr}, \mathrm{Ce} / \mathrm{Yb}$ and $\mathrm{F} / \mathrm{Rb}$ ratios to discriminate between tin mineralized and non-mineralized S-type granite. J Geosci 7:1-16

Karimpour MH, Bowes WW (1983) Application of trace elements and isotopes for discriminating between porphyry molybdenum, copper, and tin systems and the implications for predicting the grade. Glob Tecton Metallogen 2:1-16

Kwékam M, Liégeois J-P, Njonfang E, Affaton P, Hartmann G, Tchoua MF (2010) Nature, origin and significance of the Fomopéa Pan-
African high-K calc-alkaline plutonic complex in the Central African fold belt (Cameroon). J Afr Earth Sci 57:79-95

Kwékam M, Affaton P, Bruguier O, Liégeois J-P, Hartmann G, Njonfang E (2013) The Pan-African Kekem gabbro-norite (West-Cameroon), $\mathrm{U}-\mathrm{Pb}$ zircon age, geochemistry and $\mathrm{Sr}-\mathrm{Nd}$ isotopes: Geodynamical implication for the evolution of the Central African fold belt. J Afr Earth Sci 84:70-88

Lehmann B, Mahawat C (1989) Metallogeny of tin in Central Thailand: a genetic concept. Geology 17:426-429

Lentz DR (1998) Petrogenetic and geodynamic implications of extensional regimes in the phanerozoic subduction zones and their relationship to VMS-forming systems. Ore Geol Rev 12:289-327

Loucks RR (2014) Distinctive composition of copper-ore forming arc magmas. Aust J Earth Sci 61:5-16

Maniar PD, Piccoli PM (1989) Tectonic discrimination of granitoids. Geol Soc Am Bull 101:635-643

Mbassa BJ (2015) Petrographic, mineralogical, geochemical and geochronological characterizations of the magmatic formations from Mbengwi (NW-Cameroon, central Africa). Ph.D thesis, Univ Yaoundé I

Mbassa BJ, Njonfang E, Benoit M, Grégoire M, Kamgang P, Duchene S, Brunet P, Ateba B, Tchoua MF (2012) Mineralogy, geochemistry and petrogenesis of the recent magmatic formations from Mbengwi, a continental sector of the Cameroon Volcanic Line (CVL), Central Africa. Mineral Petrol 106:217-242

Mbassa BJ, Kamgang P, Grégoire M, Njonfang E, Benoit M, Itiga Z, Duchene S, Bessong M, Wonkwenmendam NP, Ntepe N (2016) Evidence of heterogeneous crustal origin for the Pan-African Mbengwi granitoids and the associated mafic intrusions (northwestern Cameroon. Central Africa). Compt Rendus Geosci 348:116-126

McDonough WF, Sun SS (1995) The composition of the Earth. Chem Geol 120:223-253

Meinert LD (1995) Compositional variation of igneous rocks associated with skarn deposits - Chemical evidence for a genetic connection between petrogenesis and mineralization. In: Thompson JFH (ed) Magmas fluids and ore deposits, Min Assoc Can Short Course Series 23:401-418

Milesi JP, Toteu SF, Deschamps Y, Feybesse JL, Lerouge C et al (2006) An overview of the geology and major ore deposits of Central Africa: Explanatory note for the 1:4.000.000 map "Geology and major ore deposits of Central Africa". J Afri Earth Sci 44:571-595

Nédélec A, Bouchez JL (2011) Pétrologie des granites, structure, cadre géologique. Collect Interact, Vuibert

Neiva AMR, Silva MMVG, Gomes MEP, Campos TFC (2002) Geochemistry of coexisting biotite and muscovite of Portuguese peraluminous granitic differentiation series. Chem Erde 62:197-215

Njanko T, Nédélec A, Affaton P (2006) Synkinematic high-K calc-alkaline plutons associated with the Pan-African Central Cameroon shear zone (W-Tibati area): petrology and geodynamic significance. J Afr Earth Sci 44:494-510

Nzenti JP, Kapajika B, Wörner G, Lubala TR (2006) Synkinematic emplacement of granitoids in a Pan-African shear zone in Central Cameroon. J Afr Earth Sci 45:74-86

Nzolang C, Kagami H, Nzenti J-P, Holtz F (2003) Geochemistry and preliminary $\mathrm{Sr}-\mathrm{Nd}$ isotopic data on the Neoproterozoic granitoids from the Bantoum area, West Cameroon. Evidence for a derivation from a Paleoproterozoic to Archean crust. Polar Geosci 16:196-226

Pearce JA, Harris NBW, Tindle AG (1984) Trace element discrimination diagrams for the tectonic interpretation of granitic rocks. J Petrol 25 : 956-983

Pei R, Hong D (1995) The granites of South China and their metallogeny. Episodes 18:77-82

Peronne Y (1969) Notice explicative sur la feuille Wum-Banyo avec carte géologique de reconnaissance au 1/500.000, Direction des Mines et de la Géologie. Yaoundé, Cameroun 
Richards JP (2011) Magmatic to hydrothermal meta flux in convergent and collided magins. Ore Geol Rev 40:1-26

Richards JP, Spell T, Rameh E, Razique A, Fletcher T (2012) High Sr/Y magmas reflect arc maturity, high magmatic water content, and porphyry $\mathrm{Cu} \pm \mathrm{Mo} \pm \mathrm{Au}$ potential: examples from the Tethyan Arcs of Central and Eastern Iran and western Pakistan. Econ Geol 107:295332

Rickwood PC (1989) Boundary lines within petrologic diagrams which use oxides of major and minor elements. Lithos 22:247-263

Rossi JN, Toselli AJ, Basei MA, Sial AN, Baez M (2011) Geochemical indicators of metalliferous fertility in the Carboniferous San Blas pluton, Sierra de Velasco, Argentina. In: Sial AN et al (eds) Granite-Related Ore Deposits. Geol Soc Vol, vol 350. Spec Pub, London, pp 175-186

Rozendaal A, Bruwer L (1995) Tourmaline nodules: mineralization in the Cape Granite Suite, South Africa. J Afr Earth Sci 21:141-155

Ruiz C, Fernández-Leyva CF, Locutura J (2008) Geochemistry, geochronology and mineralization potential of the granites in the Central Iberian Zone: the Jalama batholith. Chem Erde 68:413-429

Scheepers R (2000) Granites of the Saldania mobile belt, South Africa: radioelements and $\mathrm{P}$ as discriminators applied to metallogeny. $\mathrm{J}$ Geochem Explor 68:69-86

Shafiei B, Haschke M, Shahabpour J (2009) Recycling of orogenic arc crust triggers porphyry $\mathrm{Cu}$ mineralization in Kerman Cenozoic arc rocks, southeastern Iran. Mineral Deposita 44:265-283

Sillitoe RH (1996) Granites and metal deposits. Episodes 19:126-133
Sillitoe RH (2010) Porphyry copper systems. Econ Geol 105:3-41

Spinks SC, Uvarova Y, Thorne R, Anand R, Reid N, White A, LeyCooper Y, Bardwell N, Gray D, Meadows H, LeGras M (2017) Detection of zinc deposits using terrestrial ferromanganese crusts. Ore Geol Rev 80:484-503

Tchameni R, Pouclet A, Penaye J, Ganwa AA, Toteu SF (2006) Petrography and geochemistry of the Ngaoundéré Pan-African granitoids in central North Cameroon: implications for their sources and geological setting. J Afr Earth Sci 44:543-560

Wedepohl KH (1995) The composition of the continental crust. Geochim Cosmochim Acta 59:1217-1232

Weis D, Frey FA (1991) Isotope geochemistry of the Ninetyeast Ridge basement basalts: $\mathrm{Sr}, \mathrm{Nd}$, and $\mathrm{Pb}$ evidence for involvement of the Kerguelen hot spot. Proc Ocean Drill Program Sci Results 121:591610

Wolfe WJ (1977) Geochemical exploration of early Precambrian volcanogenic sulphide mineralization in Ben Nevis Township, District of Cochrane: Ontario. Geol Survey Study 19:39

Wu S, Zheng Y, Sun X (2016) Subduction metasomatism and collisionrelated metamorphic dehydration controls on the fertility of porphyry copper ore-forming high $\mathrm{Sr} / \mathrm{Y}$ magma in Tibet. Ore Geol Rev 73: $83-103$

Zarasvandi A, Rezaei M, Sadeghi M, Lentz D, Adelpour M, Pourkaseb H (2015) Rare earth element signatures of economic and subeconomic porphyry copper system in Urumieh-Dokhtar Magmatic Arc (UDMA), Iran. Ore Geol Rev 70:407-423 